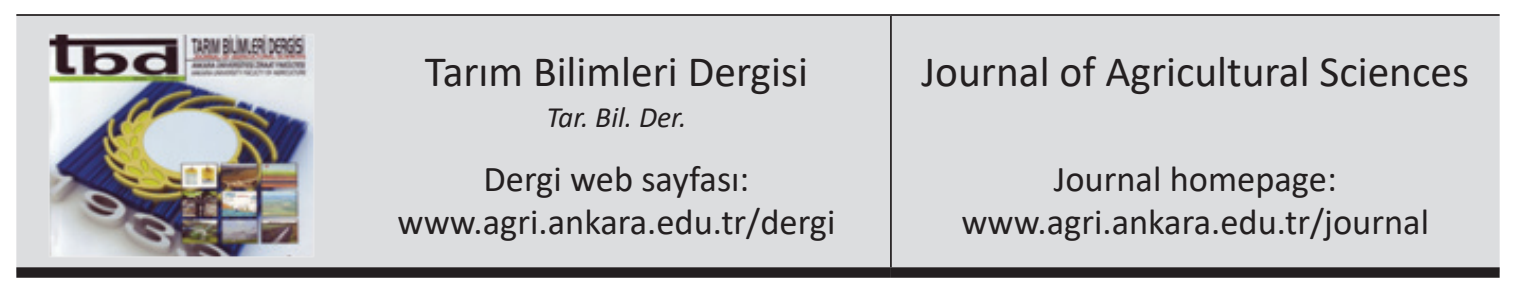

\title{
Effects of Organic Mulching on Soil Water Potential and SPAD Values as Factors on Yield of Potatoes (Solanum tuberosum $\mathbf{L}$.)
}

\author{
Petr DVOŘÁK ${ }^{\mathrm{a}}$, Martin KRÁL ${ }^{\mathrm{a}}$ \\ ${ }^{a}$ Czech University of Life Sciences Prague, Faculty of Agrobiology, Food and Natural Resources, Department of Crop Production, Kamýcká \\ 129, Prague 6- Suchdol, CZECH REPUBLIC
}

\section{ARTICLE INFO}

Research Article

DOI: 10.15832 /ankutbd.366191

Corresponding Author: Petr DVOŘÁK, E-mail: dvorakp@af.czu.cz, Tel: +420 224382540

Received: 23 December 2017, Received in Revised Form: 27 March 2018, Accepted: 30 March 2018

\begin{abstract}
In the present study, Finka and Katka potato (Solanum tuberosum L.) varieties were used at two localities (Leškovice and Uhríněves) and the effects of the surface mulching on chlorophyll content (SPAD values), soil water potential (SWP) and tuber yield of potato (YWP) were observed. Two mulching treatments (chopped grass and black polypropylene mulch) were used in the study. The results showed that plastic mulch can be an important factor for potato cultivation on localities with dystric cambisol soil type currently facing lack of precipitation. Organic mulching (with chopped grass) significantly influenced YWP. It favorably increased the fresh weight of tubers (over $60 \mathrm{~mm}$ ) per plant by $81.4 \%$ in comparison with control. Additionally, it has been found that the type of mulching or varieties can be expressed by different SPAD-yield relationship. Whereas the values of SWP and SPAD values too were not significantly affected by organic mulch, they were significantly correlated with the $\mathrm{YWP}\left(\mathrm{r}^{2}=42.4 \%, \mathrm{P}<0.0001\right.$ and $\left.\mathrm{r}^{2}=28.8 \%, \mathrm{P}<0.0023\right)$. SPAD value can predict the level of tuber yield if the value was calibrated for particular potato variety. However, the highest SPAD reading value did not guarantee the highest tuber yield.
\end{abstract}

Keywords: Grass mulch; Soil water potential; SPAD value; Potato; Yield

(C) Ankara Üniversitesi Ziraat Fakültesi

\section{Introduction}

The last fifteen years have seen increasingly frequent extreme climatic events in the Czech Republic (Rožnovský 2014) and in the Central European region (Trnka et al 2016), including the occurrence of serious drought. The extent and intensity of drought also depend on water retention capacity of the landscape. Priority should be given to increase its retention capacity through mulching to the maximum (Rožnovský 2014), especially during of high rainfalls. The principle of organic mulching (or biomass thus applied) can be used to protect the soil surface (e.g. reduce runoff and erosion). Janeček (2005) reports that more than half of agricultural land in the CR is threatened by water erosion. Water erosion causes vicissitude soil degradation, which decreases the production capacity of the soil. Meteorological phenomena such as drought (Fiala et al 2016) and extreme torrential rainfall in the $C R$ are currently a priority issue due to changing climatic conditions. Potatoes, as well as other wide-crops, are in many places in the CR associated with water erosion. Mulching may affect availability water like others physical and chemical characteristics of soil 
(Govaerts et al 2007) and enhance availability of nitrogen in the soil with increase in plant growth (Fang et al 2011). The cover of mulch influences soil moisture as well (Ramakrishna et al 2006). Mulch maintains stable soil moisture, especially in surface soil layer. The water content directly near the soil surface plays an essential role in the degradation of natural organic material by soil microbes (Hood 2001). For that reason, mulching becomes more important in moderate climate conditions. The chlorophyll (CHLO) content of a plant is a good qualitative indicator for leaf $\mathrm{N}$ concentration, and for several crops, it could be demonstrated that leaf $\mathrm{N}$ and CHLO concentration are strongly correlated (Werner et al 2005). Crop varieties differ in their genetically determined CHLO content (Minotti et al 1994; Uzik \& Zofajova 2000), what should be taken into account if CHLO measurements are used for nutrient management decisions. Additionally, variation in the CHLO contents can interfere such as plant (leaf) age (Mauromicale et al 2006) or different leaf position on the plant (Busato et al 2010). One the most common portable CHLO meter is the SPAD-502 (Minolta Co., Tokyo, Japan). The SPAD meter is a simple, portable tool that measures the greenness or relative CHLO content of leaves (Busato et al 2010). It is very quick and a non-invasive method (Denuit et al 2002). Nevertheless Denuit et al (2002), some shortcomings are reported; mainly the lack of specificity caused by the environmental effect on CHLO meter values. The potato cultivar, the soil, the climate and the water status of the crop are the main factors affecting CHLO meter values (Olivier et al 1999). Correlation with CHLO content of $\mathrm{N}$ in the laboratory conditions for potatoes is already published Vos \& Born (1993) with the result $\mathrm{r}^{2}>0.95$. In field trials, Uddling et al (2007) show a lower dependence with $r^{2}>0.58$. This study aimed to evaluate the effect of various mulches (organic and plastic mulch) on the SPAD values, soil water potential, tuber yields of potato and other parameters that may affect growth of potatoes.

\section{Material and Methods}

\subsection{Field experiments}

They were carried out at the Experimental Station of Czech University of Life Sciences Prague in Uhř́něves (50²'0.4’N, 14³6’32’'E, alt. $298 \mathrm{~m}$ asl) and Leškovice ( $49^{\circ} 45^{\prime} 46^{\prime \prime} \mathrm{N}, 15^{\circ} 32^{\prime} 16^{\prime}$ 'E, alt. $498 \mathrm{~m}$ asl) in years 2009-2011. Leškovice (LE) is a potatogrowing region, the average of annual temperature is $6.9^{\circ} \mathrm{C}$ (detailed in Table 1) and annual precipitation is $630 \mathrm{~mm}$ (weather station of the Potato Research Institute Havlíčkův Brod). The soil formed on paragneiss classified as dystric cambisol (IUSS Working Group WRB, 2015) was collected from the topsoil layer at experimental field of the Leškovice site (loam-sandy soils). Uhř́něves (UH) is sugar beet region, the average of annual temperature is $8.4^{\circ} \mathrm{C}$ and annual precipitation is $575 \mathrm{~mm}$ (meteorological station of the Czech Hydrometeorological Institute Prague Clementinum). At this site the texture class of this soil is a clay loam with an organic matter content of $1.74-2.12 \%, \mathrm{pH}$ neutral with a good reserve of all essential nutrients and the type of soil is dystric cambisol (IUSS Working Group WRB, 2015) and other hydro-physical properties show the Table 2. The field experiment comprised three

Table 1- Distribution of monthly precipitation $(\mathrm{mm})$ and air temperature $\left({ }^{\circ} \mathrm{C}\right)$ during the years $2009-2011$

\begin{tabular}{cccccccccccccccc}
\hline \multirow{2}{*}{ Year } & \multirow{2}{*}{ Site } & \multicolumn{2}{c}{$I V}$. & \multicolumn{2}{c}{$V}$. & \multicolumn{2}{c}{$V I}$. & \multicolumn{2}{c}{$V I I}$. & \multicolumn{2}{c}{$V I I I}$. & \multicolumn{2}{c}{$I X}$. & \multicolumn{2}{c}{$I V . I X}$. \\
& & $m m$ & ${ }^{\circ} \mathrm{C}$ & $m m$ & ${ }^{\circ} \mathrm{C}$ & $m m$ & ${ }^{\circ} \mathrm{C}$ & $m m$ & ${ }^{\circ} \mathrm{C}$ & $m m$ & ${ }^{\circ} \mathrm{C}$ & $m m$ & ${ }^{\circ} \mathrm{C}$ & $m m$ & ${ }^{\circ} \mathrm{C}$ \\
\hline \multirow{2}{*}{2009} & $\mathrm{LE}$ & 4.1 & 13.9 & 70.7 & 13.6 & 108.0 & 14.7 & 92.0 & 18.3 & 66.6 & 18.7 & 17.9 & 15.2 & 359 & 15.7 \\
& $\mathrm{UH}$ & 16.0 & 13.6 & 95.3 & 14.7 & 72.0 & 16.1 & 81.9 & 19.5 & 31.8 & 20.0 & 20.2 & 16.1 & 317 & 16.7 \\
\hline \multirow{2}{*}{2010} & $\mathrm{LE}$ & 151.0 & 4.3 & 101 & 11.3 & 74.0 & 16.1 & 155.2 & 18.7 & 173.0 & 16.9 & 90.0 & 10.9 & 744 & 13.0 \\
& $\mathrm{UH}$ & 32.0 & 10.1 & 93.1 & 12.6 & 62.0 & 17.9 & 118.0 & 21.6 & 139.6 & 18.6 & 106.0 & 12.4 & 551 & 15.5 \\
\hline \multirow{2}{*}{2011} & $\mathrm{LE}$ & 32.0 & 10.4 & 62.6 & 13.7 & 81.0 & 17.4 & 167.0 & 16.9 & 83.2 & 18.5 & 111.0 & 14.6 & 538 & 15.3 \\
& $\mathrm{UH}$ & 20.0 & 11.9 & 46.5 & 15.2 & 95.0 & 18.7 & 166.2 & 17.6 & 85.3 & 19.0 & 33.6 & 15.5 & 447 & 16.3 \\
\hline
\end{tabular}


Table 2- Soil characteristics of the experimental localities

\begin{tabular}{lccccc}
\hline Site & $\begin{array}{c}\text { Particle size density (determined } \\
\text { by water pycnometer method) } \\
\left(\mathrm{g} \mathrm{cm}^{-3}\right)\end{array}$ & $\begin{array}{c}\text { Saturated hydraulic conductivity } \\
\text { (determined by Ksat device) } \\
\left(\mathrm{cm} \mathrm{d}^{-1}\right)\end{array}$ & $\begin{array}{c}\text { Saturated } \\
\text { water content } \\
\left(\mathrm{cm}^{-3} \mathrm{~cm}^{-3}\right)\end{array}$ & $\begin{array}{c}\text { Dry bulk } \\
\text { density } \\
\left(\mathrm{g} \mathrm{cm}^{-3}\right)\end{array}$ & $\begin{array}{c}\text { Porosity } \\
(\%)\end{array}$ \\
\hline $\mathrm{LE}$ & 2.709 & 77 & 0.487 & 1.30 & 52 \\
$\mathrm{UH}$ & 2.645 & 1025 & 0.464 & 1.15 & 57 \\
\hline
\end{tabular}

mulch treatments in a randomized block design with four replicates and plot size $7.2 \mathrm{~m}^{2}$. Pre-sprouted seed tubers were hand-planted. Rows were apart $0.8 \mathrm{~m}$, seed potatoes were placed $0.33 \mathrm{~m}$ apart in the rows. The plow and organic fertilization (no other nutrients were applied) were used and disease control were done according to organic agriculture (same for all treatments).

\subsection{Mulching}

The mulching with chopped grass (OM) and black textile mulch (PM) were compared to non-mulching control variant $(\mathrm{C})$ with the mechanical cultivation (3 times up to closed crops and one before emergence). $\mathrm{OM}$ is material from natural meadows Dactylis glomerata - 40\%, Festuca pratensis - 20\%, Lolium perenne - 20\%, Poa pratensis - 10\%, Alopecurus pratensis - $10 \%$. OM was manually spread in a 25 $\mathrm{mm}$ thick layer $14^{\text {th }}$ day after planting (immediately after second hoeing). In plots with PM ridges were formed firstly and then covered by the black polypropylene non-woven textile and subsequently hand planted.

\subsection{Soil water potential (SWP)}

It was measured in all treatments (OM, PM and C) at the depth of $240 \mathrm{~mm}$ in 30-min intervals during period from planting to harvest with sensor Watermark 200SS-X cooperating with MicroLog SP (EMS, Brno).

\subsection{Soil and plant analysis department (SPAD values)}

After complete plant emergence, a SPAD was measured in the second fully expanded leaf from the apex. The readings were recorded in ten plants of each plot. The SPAD was determined by the SPAD-
502 portable chlorophyll meter (Minolta Co, Tokyo, Japan). SPAD 502 meter is a small handy device, which measures light transmittance at red $(650 \mathrm{~nm}$, chlorophyll absorption) and near-infrared $(960 \mathrm{~nm})$ wavelength (Minolta 1989). The strong correlation of chlorophyll concentration and SPAD value were validated for a range of crops including potato (Vos $\&$ Born 1993). The SPAD readings were carried out in the morning, between 8:00 and 11:00 a.m. at $42,57,66,76,83$ and 90 days after planting (DAP) on the same plants. The experiments carried out by Gianquinto et al (2004) showed that SPAD readings correlated to corresponding crop nitrogen content and then the highest coefficient of determination that was observed 32 days after emergence, at growing stage middle flowerings bud (about 15 days after tuber initiation). This stage is mentioned in SPAD readings. The SPAD values were correlated with YWP.

\subsection{Weeds}

The weight of weed biomass (WB) in all treatments were determined before harvest when the weeds were removed.

\subsection{Harvest, measurement of the yield and statistical analysis}

Tubers were harvested by hand. YWP (tubers $>$ $40 \mathrm{~mm}$ ) was determined for each plot. Data were subjected to analysis of variance using the ANOVA procedure and correlation (Pearson correlation coefficients) with SAS ver. 9.1.3. (SAS Institute Inc. 2003). Means were separated using Turkey's test at $95 \%$ level of probability only when the ANOVA F-test showed significant at 0.05 or 0.01 probability levels. 


\section{Results}

\subsection{Evaluation of soil water potential}

SWP was variable (in vegetation of average from 22.4 to $119.7 \mathrm{kPa}$ ) due to rainfall (Table 3) and mulching materials at experimental sites. SWP developments during the year were strongly influenced by sum of rainfall and its distribution during the year. Nevertheless SWP was generally lower (respectively higher soil moisture) in the $\mathrm{OM}$ and $\mathrm{PM}$ treatments than in the $\mathrm{C}$ variant. Significant SWP differences in mulching treatment were observed in LE, where SWP levels were lower compared to UH (Table 3).

\subsection{Evaluation of weed biomass}

The type of mulch material affected the presence of weeds (Table 3). The lowest WB were found in PM (WB by $66.3 \%$ lower than C). The trend of lower WB was also at OM (lower by $11.7 \%$ comparison with C). The negative correlation between WB and YWP were not found in any of the experimental variants.

\subsection{SPAD reading}

Potatoes with the OM were characterized by the highest SPAD values (by 5.0\%, 5.5\% and $0.6 \%$ in 2009, 2010 and 2011) compared with C (Table 3). Similarly, the second-highest SPAD values were achieved with PM (on both sites in average 2009-2011). SPAD value at OM showed a medium correlation to yield of ware potatoes $(\mathrm{r}=0.5363$, $\mathrm{P}=0.0023$ ) and next yield components (Table 4). While at the PM was found a strong correlation $(r=$ $0.6572, \mathrm{P}<0.0001)$ between $\mathrm{SPAD}$ values and tuber yields (Table 5).

\subsection{Yield of ware potatoes}

The type of mulch material affected the YWP (Table 3 ). The highest YWP was found when using OM by $26.6 \%$ compared with $\mathrm{C}\left(28.5 \mathrm{t} \mathrm{ha}^{-1}\right)$. An application of OM (Figure 1) resulted in a significant increase weight of ware potatoes (fraction 55-60 mm and especially fraction over $60 \mathrm{~mm}$ ). YWP after application of black plastic textile (PM) was similar with control. The fall of YWP at PM was recorded in UH in 2009 and 2010 (Table 3). On the contrary, during the period of tuber growth, in 2011 there was approximately $80-100 \mathrm{~mm}$ of precipitation more than in previous years (Table 1) and the yield of tubers was higher for PM.

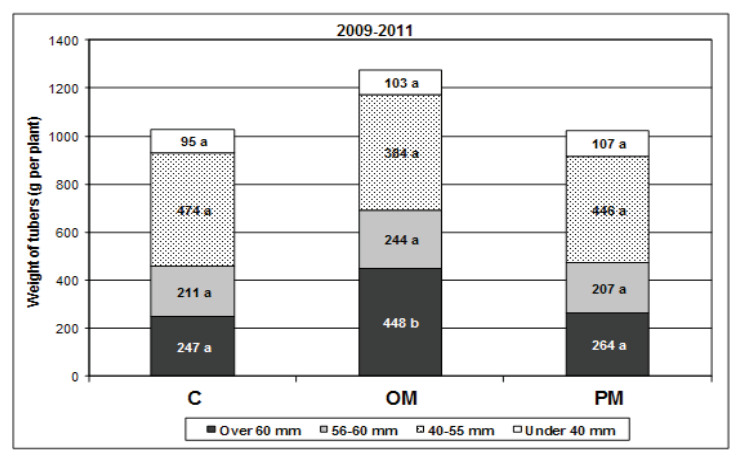

Figure 1- Weight of tubers in specific size fractions for each type of mulching (Note: same letters indicate statistically not significant differences; HSD $_{0.05}($ over $60 \mathrm{~mm})=129.6, \mathrm{HSD}_{0.05}(56-60 \mathrm{~mm})=$ 56.00, HSD $_{0.05}(40-55 \mathrm{~mm})=\mathbf{7 1 . 1 3}, \mathrm{HSD}_{0.05}$ (under 40 $\mathbf{m m})=19.82$ )

\section{Discussion and Conclusions}

The significant differences of SWP were not observed in less rainfall locality in treatment of plastic mulching (Table 3). Link \& Bower (2004) also examined the effect of plastic mulch type (permeable and non-permeable) on soil water potential too in a semi-arid ecosystem and plastic mulch had no effect on soil moisture retention (in depths 10, 30 and $60 \mathrm{~cm}$ in 12 experiments). However, SWP had the largest Pearson correlation coefficient $(r)$ for the yield of ware potatoes (YWP) from the following factors (SWP, SPAD and WB). For control variant $(C) r=-0.7188, P<0.0001$, for $\mathrm{OM} \mathrm{r}=-0.6509, \mathrm{P}<0.0001$ and for $\mathrm{PM} \mathrm{r}=-0.7391$, $\mathrm{P}<0.0001$ (Table 4, 5 and 6).

On the other hand, polypropylene (PP) textile had a positive effect on weed control in this experiment (Table 3), like similar polyethylene (PE) mulch (Ramakrishna et al 2006). We are convinced that total levels of WB were low during the main growth 
Table 3- SPAD value, rainfall on vegetation, soil water potential and weight of tubers affected by different types of mulching materials (2009-2011)

\begin{tabular}{|c|c|c|c|c|c|c|c|}
\hline Locality & $\begin{array}{l}\text { Variant of } \\
\text { mulching }\end{array}$ & $\begin{array}{l}\text { Rainfall on } \\
\text { vegetation } \\
(\mathrm{mm})\end{array}$ & $\begin{array}{c}\text { Soil water } \\
\text { potential } \\
(\mathrm{kPa})\end{array}$ & $\begin{array}{c}\text { Yield of ware } \\
\text { potatoes } \\
\left(t h a^{-1}\right)\end{array}$ & $\begin{array}{c}\text { Weed } \\
\text { biomass } \\
\left(\mathrm{g} \mathrm{m}^{-2}\right)\end{array}$ & $\begin{array}{l}\text { SPAD } \\
\text { values }\end{array}$ & $\begin{array}{c}\text { Total tuber } \\
\text { yield } \\
\left(t h a^{-1}\right)\end{array}$ \\
\hline & & \multicolumn{6}{|c|}{2009} \\
\hline \multirow{4}{*}{ LE } & $\mathrm{C}$ & \multirow{4}{*}{359.00} & 33.82 & 30.03 & 175.94 & 38.91 & 32.62 \\
\hline & $\mathrm{OM}$ & & 35.62 & 32.69 & 31.60 & 42.70 & 35.82 \\
\hline & PM & & 21.33 & 32.38 & 7.31 & 42.06 & 36.43 \\
\hline & $\mathrm{C}$ & & 57.04 & 30.34 & 38.33 & 35.63 & 32.52 \\
\hline \multirow[t]{3}{*}{ UH } & $\mathrm{OM}$ & \multirow[t]{3}{*}{317.00} & 36.50 & 35.49 & 88.99 & 36.18 & 37.51 \\
\hline & PM & & 67.24 & 23.67 & 0.35 & 35.71 & 26.54 \\
\hline & $\mathrm{C}$ & & 45.43 & $30.22 \mathrm{AB}$ & $98.42 \mathrm{~A}$ & 36.94 & $32.56 \mathrm{~B}$ \\
\hline \multirow{4}{*}{$\begin{array}{l}\text { Average } \\
\text { of localities }\end{array}$} & $\mathrm{OM}$ & \multirow{3}{*}{--} & 36.06 & $34.37 \mathrm{~A}$ & $68.13 \mathrm{~A}$ & 38.79 & $36.84 \mathrm{~A}$ \\
\hline & $\mathrm{PM}$ & & 44.29 & $27.15 \mathrm{~B}$ & $3.21 \mathrm{~B}$ & 38.25 & $30.50 \mathrm{~B}$ \\
\hline & $\mathrm{HSD}_{0.05}$ & & NS & 4.16 & 63.18 & NS & 4.02 \\
\hline & & \multicolumn{6}{|c|}{2010} \\
\hline \multirow{4}{*}{ LE } & $\mathrm{C}$ & \multirow{4}{*}{744.00} & 36.93 & 43.97 & 229.01 & 37.37 & 48.49 \\
\hline & $\mathrm{OM}$ & & 37.35 & 52.48 & 252.12 & 39.37 & 57.02 \\
\hline & PM & & 29.67 & 34.55 & 58.49 & 38.41 & 40.04 \\
\hline & $\mathrm{C}$ & & 108.55 & 17.69 & 90.33 & 28.11 & 22.97 \\
\hline \multirow[t]{3}{*}{$\mathrm{UH}$} & $\mathrm{OM}$ & \multirow[t]{2}{*}{551.00} & 119.72 & 21.72 & 71.70 & 29.68 & 27.50 \\
\hline & PM & & 99.89 & 14.64 & 4.58 & 28.53 & 19.35 \\
\hline & $\mathrm{C}$ & \multirow{4}{*}{--} & 72.74 & $28.20 \mathrm{~B}$ & $151.9 \mathrm{~A}$ & $31.81 \mathrm{~B}$ & $33.18 \mathrm{~B}$ \\
\hline \multirow{5}{*}{$\begin{array}{l}\text { Average } \\
\text { of localities }\end{array}$} & OM & & 78.54 & $34.03 \mathrm{~A}$ & $147.2 \mathrm{~A}$ & $33.56 \mathrm{~A}$ & $39.30 \mathrm{~A}$ \\
\hline & $\mathrm{PM}$ & & 64.78 & $22.60 \mathrm{C}$ & $35.04 \mathrm{~B}$ & $32.48 \mathrm{~B}$ & $27.63 \mathrm{C}$ \\
\hline & $\mathrm{HSD}_{005}$ & & NS & 5.16 & 87.46 & 1.02 & 4.69 \\
\hline & & \multicolumn{6}{|c|}{2011} \\
\hline & $\mathrm{C}$ & \multirow{4}{*}{538.00} & 29.58 & 29.33 & 506.13 & 37.33 & 30.82 \\
\hline \multirow[t]{3}{*}{ LE } & $\mathrm{OM}$ & & 22.38 & 45.07 & 406.37 & 37.27 & 47.49 \\
\hline & PM & & 25.22 & 49.29 & 341.75 & 39.47 & 50.60 \\
\hline & $\mathrm{C}$ & & 93.19 & 25.43 & 147.41 & 39.74 & 26.37 \\
\hline \multirow[t]{3}{*}{ UH } & $\mathrm{OM}$ & \multirow[t]{2}{*}{447.00} & 91.43 & 36.09 & 149.76 & 40.14 & 37.00 \\
\hline & PM & & 101.66 & 26.39 & 10.61 & 38.41 & 27.54 \\
\hline & $\mathrm{C}$ & \multirow{4}{*}{--} & 61.39 & $26.99 \mathrm{~B}$ & $283.80 \mathrm{~A}$ & 38.77 & $28.15 \mathrm{~B}$ \\
\hline \multirow{4}{*}{$\begin{array}{l}\text { Average } \\
\text { of localities }\end{array}$} & $\mathrm{OM}$ & & 56.91 & $39.68 \mathrm{~A}$ & $256.50 \mathrm{~A}$ & 38.99 & $41.19 \mathrm{~A}$ \\
\hline & PM & & 63.44 & $35.55 \mathrm{~A}$ & $141.80 \mathrm{~B}$ & 38.83 & $36.76 \mathrm{~A}$ \\
\hline & $\mathrm{HSD}_{005}$ & & NS & 6.28 & 87.40 & NS & 6.16 \\
\hline & & \multicolumn{6}{|c|}{$2009-2011$} \\
\hline \multirow{4}{*}{ Average } & $\mathrm{C}$ & \multirow{4}{*}{--} & 59.85 & $28.47 \mathrm{~B}$ & $178.10 \mathrm{~A}$ & $35.84 \mathrm{~A}$ & $31.30 \mathrm{~B}$ \\
\hline & $\mathrm{OM}$ & & 57.17 & $36.03 \mathrm{~A}$ & $157.30 \mathrm{~A}$ & $37.11 \mathrm{~A}$ & $39.11 \mathrm{~A}$ \\
\hline & PM & & 57.50 & $28.44 \mathrm{~B}$ & $60.02 \mathrm{~B}$ & $36.52 \mathrm{~A}$ & $31.63 \mathrm{~B}$ \\
\hline & $\mathrm{HSD}_{005}$ & & NS & 3.95 & 50.19 & 1.79 & 3.78 \\
\hline
\end{tabular}

Means accompanied by the same letters are not significantly different at $\mathrm{P} \leq 0.05$ 
Table 4- Correlational relationship for organic mulch (with chopped grass)

\begin{tabular}{lllllll}
\hline OM & WT 55-60 mm & WT over $60 \mathrm{~mm}$ & YWP & WB & SPAD & SWP \\
\hline WT 55-60 mm & 1.000 & 0.2516 & $0.5636^{* *}$ & 0.1338 & $0.6301^{* * *}$ & $-0.5942^{* * *}$ \\
WT over 60 mm & & 1.000 & $0.6410^{* * *}$ & 0.2239 & $0.4763^{* *}$ & -0.3275 \\
YWP & & & 1.000 & $0.4974^{* *}$ & $0.5363^{* *}$ & $-0.6509^{* * *}$ \\
WB & & & 1.000 & 0.1044 & $-0.3662^{*}$ \\
SPAD & & & & 1.000 & $-0.5538^{* *}$ \\
SWP & & & & & 1.000
\end{tabular}

Weight of tubers fraction 55-60 mm (WT 55-60 mm), weight of tubers fraction over $60 \mathrm{~mm}$ (WT over $60 \mathrm{~mm}$ ); significant differences of correlation test ${ }^{*}, \mathrm{P}<0.05 ;{ }^{* *}, \mathrm{P}<0.01 ;{ }^{* * *}, \mathrm{P}<0.001$

Table 5- Correlational relationship for plastic mulch (black polypropylene textile)

\begin{tabular}{lllllll}
\hline PM & WT 55-60 mm & WT over $60 \mathrm{~mm}$ & YWP & WB & SPAD & SWP \\
\hline WT 55-60 mm & 1.000 & $0.5541^{* *}$ & $0.8561^{* * *}$ & $0.3865^{*}$ & $0.5756^{* * *}$ & $-0.5864^{* * *}$ \\
WT over $60 \mathrm{~mm}$ & & 1.000 & $0.6974^{* * *}$ & $0.5815^{* * *}$ & $0.4922^{* *}$ & -0.1935 \\
YWP & & & 1.000 & $0.6496^{* * *}$ & $0.6572^{* * *}$ & $-0.7391^{* * *}$ \\
WB & & & 1.000 & 0.2225 & $-0.4404^{*}$ \\
SPAD & & & & 1.000 & $-0.6265^{* * *}$ \\
SWP & & & & & 1.000 \\
\hline
\end{tabular}

Significant differences of correlation test ${ }^{*}, \mathrm{P}<0.05 ;{ }^{* *}, \mathrm{P}<0.01 ;{ }^{* * *}, \mathrm{P}<0.001$

Table 6- Correlational relationship for control variant (without mulching)

\begin{tabular}{lllllll}
\hline Control & WT 55-60 mm & WT over $60 \mathrm{~mm}$ & YWP & WB & SPAD & SWP \\
\hline WT $55-60 \mathrm{~mm}$ & 1.000 & $0.4396^{*}$ & $0.5209^{* *}$ & 0.2002 & $0.5677^{* *}$ & $-0.5615^{* *}$ \\
WT over 60 mm & & 1.000 & $0.6221^{* * *}$ & -0.1117 & $0.3774^{*}$ & -0.1434 \\
YWP & & 1.000 & 0.2463 & $0.3893^{*}$ & $0.7188^{* * *}$ \\
WB & & & 1.000 & 0.2009 & $-0.5243^{* *}$ \\
SPAD & & & & 1.000 & $-0.4691^{* *}$ \\
SWP & & & & & 1.000 \\
\hline
\end{tabular}

Significant differences of correlation test ${ }^{*}, \mathrm{P}<0.05 ;{ }^{* *}, \mathrm{P}<0.01 ;{ }^{* * *}, \mathrm{P}<0.001$

period of tubers in all experimental variants. It was a late occurrence of weeds when the growth of the tuber and the yield of the tubers was completed. It was not about nutrient and water competition in this case. Therefore the correlation relationship between WB (determined before harvest) and YWP has been confirmed for OM and PM (Table 4 and 5). Although plastic foils are used in crop production for weed control, they have many disadvantages (Warnick et al 2006). Polyethylene foil is impermeable to precipitations and has less strength (in contrast to PP textile). Therefore, the PP textile can be used as multi-year.

Higher SPAD values, respectively higher CHLO content at mulch stands testify to their better vitality, since, as mentioned Boochs et al (1990) a loss of vitality expressed in a reduction of the CHLO content and lowers the absorption of photosynthesis active radiation (PAR). The correct use of CHLO meter 
can give a quick and accurate estimation of both crop nitrogen status and final YWP (Gianquinto et al 2004). We believe that increased SPAD values (Figure 2) also guarantee an increase $N$ content in plants, respectively increase of the tuber yield. We proceed from the known truth about correlation SPAD and nutritional status respectively, $\mathrm{N}$ content in potato leaves (Gianquinto et al 2004). The relationship of chlorophyll content and the yield of tubers is evident here (the highest yield of tubers and the highest SPAD values for OM). Likewise, as expressed by the correlation coefficient for $\mathrm{OM}\left(\mathrm{r}=0.5363, \mathrm{r}^{2}=28.8 \%\right.$, $\mathrm{P}=0.0023)$. An even stronger correlation was found for $\mathrm{PM}\left(\mathrm{r}=0.6572, \mathrm{r}^{2}=43.2 \%, \mathrm{P}<0.0001\right)$. Gianquinto et al (2004) also showed the dependence of the SPAD levels at different sampling dates and the final yield of potato tubers in the variety Primura. This coefficient of determination ranged from $\mathrm{r}^{2}=56.3 \%$ to $\mathrm{r}^{2}=83.5 \%$ in their experiments.

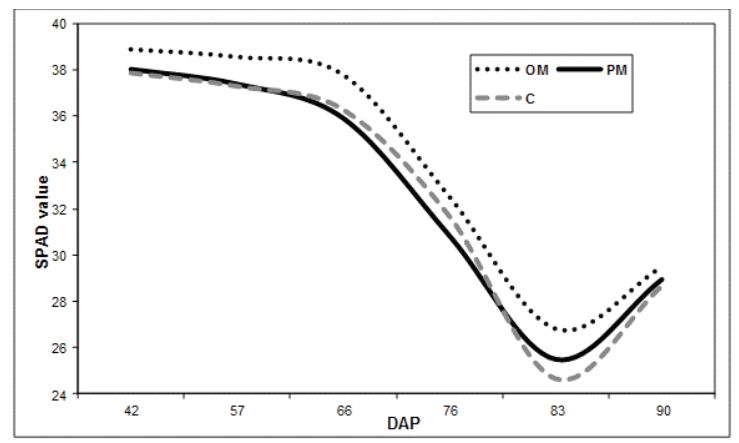

Figure 2- The evolution of SPAD values on plots with organic mulch (OM), plastic mulch (PM) and control variant $(\mathrm{C})$

OM favorably influenced the conditions during vegetation and it showed a yield increase of 7.6 $\mathrm{t} \mathrm{ha}^{-1}$. The Increase of tuber yield up to $10 \mathrm{t} \mathrm{ha}^{-1}$ was mentioned in connection with the mulching potatoes within Momirovic et al (1997).

It is difficult to achieve greater representation (proportion) of ware potatoes (tubers $55-75 \mathrm{~mm}$ ) in organic cultivation. Sawicka et al (2007) show that comparison of the systems (ecological and conventional) and years had the strongest effect on the share of the weight of the tubers with a diameter
$>6 \mathrm{~cm}$ as well as tuber yield of ware potatoes. The use of OM helped to significantly increase of fraction biggest tubers (over $60 \mathrm{~mm}$ ) and tuber fraction 55$60 \mathrm{~mm}$, which are popular for big consumers.

On the other hand, lower tuber yields were in accordance with the less favorable soil moisture and SWP for PM (at the term intensive growth of tubers in June and July). Due to textiles and worse rainfall penetration there was an increase SWP and yield depression, especially in the warmer and in rain poor locality as UH in 2009 and 2010 (Table 1 and 3 ). Therefore, we experienced higher the seasonal fluctuations in the yields of tubers at PM, on the contrary, OM stabilized the yield of tubers on the two soil-climatically different localities (LE a UH).

Based on the availability of data from the database of soil hydrophysical characteristics of the Czech Republic (Miháliková et al 2013), it is possible to derive soil hydrophysical properties from easily accessible soil properties. The diversity of precipitations and soil types at both experimental sites (LE and UH) deepens the information on the possibilities and benefits of using definite mulch material (OM or PM).

In conclusion, the expected production of organic potatoes can be based on the application of chopped grass as organic mulching. However, the highest SPAD reading value did not guarantee the highest tuber yield.

\section{Acknowledgements}

The Ministry of Education, Youth, and Sports CR, S" Grant, Technology Agency of the Czech Republic, Project No. TJ01000071 supported this research.

\section{References}

Boochs F, Kupfer G, Dockter K \& Kuhbauch W (1990). The shape of the red edge as vitality indicator for plants. International Journal of Remote Sensing 11: 1741-1753

Busato C, Fontes P C R, Braun H \& Cecon P R (2010). Seasonal variation and threshold values for chlorophyll meter readings on leaves of potato cultivars. Journal of Plant Nutrition 33: 2148-2156 
Denuit J P, Olivier M, Goffaux M J, Herman J L, Goffart J P, Destain J P \& Frankinet M (2002). Management of nitrogen fertilization of winter wheat and potato crops using the chlorophyll meter for crop nitrogen status assessment. Agronomie 22: 847-853

Fang S Z, Xie B D, Liu D \& Liu J J (2011). Effects of mulching materials on nitrogen mineralization, nitrogen availability and poplar growth on the degraded agricultural soil. New Forests 41: 147-162

Fiala R, Kohut M, Chuchma F \& Rožnovský J (2016). Agricultural drought in the Czech Republic in the year 2015. In: Rožnovský J, Vopravil J. (Eds). Soil and Agriculture Drought; 2016 Research Institute for Soil and Water Conservation, April 28, Kutná Hora, pp. 66-81

Gianquinto G, Goffart J E, Olivier M, Guarda G, Colauzzp M, Costa L D, Vedove G D, Vos J \& Mackerron D K L (2004). The use of hand-held chlorophyll meters as a tool to assess the nitrogen status and to guide nitrogen fertilization of potato crop. Potato Research 47(5): 35-80

Govaerts B, Sayre K D, Lichter K, Dendooven L \& Deckers J (2007). Influence of permanently raised bed planting and residue management on physical and chemical soil quality in rainfed maize- wheat systems. Plant and Soil 291: 39-54

Hood R (2001). The effect of soil temperature and moisture on organic matter decomposition and plant growth. Isotopes in Environmental and Health Studies 37: 25-41

IUSS Working Group WRB (2015). World Reference Base for Soil Resources 2014, Update 2015. International Soil Classification System for Naming Soils and Creating Legends for Soil Maps. World Soil Resources Reports No: 106, Rome

Janeček M (2005). Protection of agricultural land against erosion processes, ISV Publishing, Prague

Link S O \& Bower A (2004). Effect of mulch type and width on soil Water potential and plant survivorship in a semi-arid riparian ecosystem. Northwest Science 78(4): $334-338$

Mauromicale G, Ierna A \& Marchese M (2006). Chlorophyll fluorescence and chlorophyll content in field-grown potato as affected by nitrogen supply, genotype, and plant age. Photosynthetica 44: 76-82

Miháliková M, Matula S \& Doležal F (2013). HYPRESCZ - a database of soil hydrophysical properties in the Czech Republic. Soil \& Water Research 8: 34-41

Minolta (1989). Chlorophyll meter SPAD-502. Instruction manual. Minolta Co., Ltd., Radiometric Instruments Operations, Osaka, Japan
Minotti P L, Halseth D E \& Sieczka J B (1994). Field chlorophyll measurements to assess the nitrogen status of potato varieties. HortScience 29: 1497-1500

Momirovic N M, Mišovic M M \& Brocic Z A (1997). Effect of organic mulch application on the yield of potato seed crop. Acta Horticulturae (ISHS) 462: 291-296

Olivier M, Goffart J P \& Sinnave G (1999). Evaluation of an invasive method to assess the nitrogen status of the potato in the course of the season. In: Proceedings of the $14^{\text {th }}$ Triennial Conference of the European Association for Potato Research, 2-7 May 1999, Sorrento, Italy, pp. 134-135

Ramakrishna A, Tam H M, Wani S P \& Long T D (2006). Effect of mulch on soil temperature, moisture, weed infestation and yield of groundnut in Northern Vietnam. Field Crops Research 95: 115-125

Rožnovský J (2014). Drought in the Czech Republic. Živa $1: 2-3$

Sawicka B, Barbaś P \& Kuś J (2007). Variability of potato field and its structure in organic and integrated crop production systems. Electronic Journal of Polish Agricultural Universities, Agronomy [online], 10(1): \#02. ISSN 1505-0297. On-line 16.5.2017 http:// wwwejpau.media.pl/ volumne10/issue1/ art.-02.html

Trnka M, Balek J, Štěpánek P, Zahradníček P, Možný M, Eitzinger J, Žalud Z, Formayer H, Turňa M, Nejedlík P, Semerádová D, Hlavinka P \& Brázdil R (2016). Drought trends over part of Central Europe between 1961 and 2014. Climate Research 70: 143-160

Uddling J, Gelang-Alfredsson J, Piikki K \& Pleijel H (2007). Evaluating the relationship between leaf chlorophyll concentration and SPAD-502 chlorophyll meter readings. Photosynthesis Research 91: 37-46

Uzik M \& Zofajova A (2000). Chlorophyll and nitrogen content in leaves of winter wheat at different genotypes and fertilization. Rostlinná Výroba 46: 237-244

Vos J \& Born M (1993). Hand-held chlorophyll meter: a promising tool to assess the nitrogen status of potato foliage. Potato Research 36: 301-308

Warnick J, Chase C, Rosskopf E, Simonne E, Scholberg J, Koenig R \& Roe N (2006). Weed suppression with hydramulch, a biodegradable liquid paper mulch in development. Renewable Agriculture and Food Systems 21(4): 216-223

Werner O, Blankenau K, Brentrup F, Jasper J, Link A \& Lammel J (2005). Soil- and plant-based nitrogenfertilizer recommendations in arable farming. Journal of Plant Nutrition and Soil Science 168: 414-431 